\title{
PRAGMATIC PHENOMENA CONSTELLATION IN SPECIFIC CULTURE DIMENSION LANGUAGE STUDY
}

\author{
R. Kunjana Rahardi \\ Masters Program in the Indonesian Language and Literature Education \\ Sanata Dharma University Yogyakarta \\ kunjana.rahardi@gmail.com; kunjana@usd.ac.id \\ DOI: https://doi.org/10.24071/ijhs.2017.010109 \\ received 14 April 2016; revised 15 February 2017; accepted 25 June 2017
}

\begin{abstract}
The linguistic phenomena studied in pragmatics evolve over time. Among the pragmatic phenomena that can be mentioned here are: implicature, deixis, presupposition, entailment, language politeness, language impoliteness and language phatic. There are certainly other pragmatic phenomena outside the phenomena mentioned above. In the future, other new pragmatic phenomena are expected to arise, along with the better development of pragmatic studies. Among those pragmatic phenomena, the phenomenon of language impoliteness can be regarded as a new phenomenon. How the constellation of pragmatic phenomena in the language study with the specific culture perspective becomes the main issue discussed in this short article. The benefit obtained by understanding the constellation of this new pragmatic phenomenon is that the interpretation of the pragmatic intent or meaning of language impoliteness becomes increasingly sharp, profound and comprehensive because its association with other pragmatic phenomena is sometimes an inevitable fact.
\end{abstract}

Keywords: phatic language, linguistic impoliteness, pragmatic phenomenon, specific culture

\section{Introduction}

Pragmatics is a branch of language science that is 'context bound' or 'context dependent' in nature. That is, in pragmatics, the intent of the speaker or the pragmatic meaning can only be interpreted by taking the context into account. Pragmatics differs from linguistics in terms of contextual obsolescence used as a basis in the analysis process. Therefore, the meaning in pragmatics can also be said to be triadic, while the meaning in linguistics is said to be dyadic. The meaning in pragmatics is triadic because of the existence of the context. Leech (1983) mentions that the context in pragmatics differs from the context in linguistics. The context in linguistics is called co-text, while the context in pragmatics is called speech situational context.

Over time, along with the development of science and technology, the context in pragmatics has become more varied and complex. Along with the development of such varied and complex contexts, pragmatics as a branch of language science evolved as well as its complexity. The linguistic phenomena 
studied in pragmatics evolve over time. Among those pragmatic phenomena, the phenomenon of language impoliteness can be regarded as a new phenomenon. How the constellation of pragmatic phenomena in the language study with specific culture dimension becomes the main issue discussed in this article. The benefit obtained by understanding the constellation of this pragmatic phenomenon is that the interpretation of the pragmatic intent or meaning of each pragmatic phenomenon will become increasingly sharp, profound and comprehensive because the relation between pragmatic phenomena is sometimes inevitable.

\section{Method}

Data collection methods used in this study were listening method and speaking method (Sudaryanto, 2015). Some techniques used in the implementation of the two methods above were the taking notes technique, recording technique, and fishing technique. There were two kinds of data analysis methods used in this study, which were distributional analysis method and equivalent analysis method (Sudaryanto, 2015). The distributional analysis method was used to describe the linguistic dimensions of language studies in the specific culture perspective. The equivalent analysis method was used to reach the pragmatic dimensions of this linguistic study. Furthermore, each method used for analyzing the data was detailed by both basic techniques and advanced techniques. Since this study was of pragmatic dimension, it had to be emphasized that the equivalent method applied was the extralingual equivalent method. What were paired were nonlinguistic entities that were essentially outside the language, or which in linguistic studies are commonly referred to as extralinguistic factors. The distributional method was applied by using dividing technique for both dividing technique which was direct in nature and dividing technique which was indirect in nature towards the elements of speech that contained language phatic as the object of the study (Rahardi et al, 2015).

\section{Findings and Discussion}

On several occasions, the researcher has conveyed the idea that as a new pragmatic phenomenon, language impoliteness must continue to be inflated. The findings of language studies pragmatically on a certain specific culture basis must be communicated to the public so that this linguistic phenomenon is increasingly understood by the public. The phenomenon of language impoliteness can be said to have only begun since Bousfield et al. (2008) wrote a book entitled 'Impoliteness in Language'. The researcher believes that the presence of the book was a milestone in the emergence of the studies of language impoliteness. The incredible passion in the study of language politeness emerged since Fraser (1994) presented four views to assess politeness, and the study of language impoliteness by Bousfiled et al. (2008) was the milestone. In a book written by Bousfield et al. (2008), a number of views on language impoliteness are described in detail as follows.

The view of Locher (2008) which asserts that language impoliteness is '... behaviour that is face-aggravating in a particular context.' Essentially, language impoliteness refers to face-aggravating attitudes and behaviors. Face-aggravating behavior is different from face-threatening behavior as offered in various definitions of classic language politeness, such as Leech (1983), Brown and 
Levinson (1987), or earlier studies in 1978 that tend to be influenced by the face concept of Goffman (cf. Rahardi, 2009). The difference is that in faceaggravation, there is a dimension of insult and/or humiliation against one's face. Another interpretation that is related to Locher's (2008) definition of the phenomenon of language impoliteness is that the actions are not just the attitudes and behaviors that make a person's face aggravated, but a behavior that 'plays someone's face'.

In the view of Bousfield (2008), language impoliteness is understood as, 'The issuing of intentionally gratuitous and conflictive face-threatening acts (FTAs) that are purposefully perfomed.' Bousfield (2008) emphasizes the dimension of 'gratuitous' in the practice of impolite language. Therefore, if a person's language behavior is face-threatening, and the threat to the face is done gratuitously, until the gratuitous category action brings conflict, or even quarrel, and the action is done in purpose, then the act of language is a reality of language impoliteness.

Culpeper's (2008) understanding on language impoliteness is described as follows, 'Impoliteness, as I would define it, involves communicative behavior intending to cause the "face loss" of a target or perceived by the target to be so.' He gives emphasis to the fact of 'face loss' - if in Javanese it may be close to the concept of 'ilang raine' [losing the face], or 'ra duwe rai' [no face], or 'kelangan $r a i^{\prime}$ [loss of face]. Therefore, impoliteness in language is a communicative behavior that is intentionally tuned to make a person really experiences face loss, or at least the person 'feels' losing his or her face.

Terjourafi (2008) considers impoliteness as, 'impoliteness occurs when the expression is not conventionalized relative to the context of occurrence; It threatens the addressee's face but no face-threatening intention is attributed to the speaker by the hearer.' Thus, the language behavior is said to be impolite when the addressee feels a threat of face threatening act, and the speaker does not get the face threat intention from the addressee. They argue that impolite behavior is the negatively marked behavior, because it violates the social norms prevailing in the society. In addition, they assert that impoliteness is a means to negotiate meaning. Furthermore, their views on language impoliteness are presented as follow, '... impolite behavior and face-aggravating behavior more generally is as much as this negation as polite versions of behavior.' (cf. Lohcer \& Watts, 2008, p.5).

As mentioned earlier, in the pragmatic studies that have developed so far, the study of impoliteness is not one of the phenomena to be studied. One of the reasons underlying the absence of impoliteness as a pragmatic phenomenon is that the study of language impoliteness is considered to be paired with politeness. Like a natural phenomenon, what happens is bipolar in nature, the good is paired with the bad, the natural is paired with the unnatural, and so on. The same thing is applied in the pragmatic context, the advantageous is paired with the disadvantageous. Leech also has the same argument, the polite is paired with the impolite, the advantageous is paired with the disadvantageous. Therefore, such a bipolar reason is one of the reasons why language impoliteness is not a phenomenon in the pragmatic study. Another reason that causes language impoliteness not being made a separate phenomenon in pragmatics is because the society is always oriented to what is polite in behaving in the society, not the impolite one. Thus, what is important for them to learn is something polite, not 
something that is impolite. In other words, there is a kind of assumption that the study of impoliteness is not really necessary in the society because the society certainly will not commit impoliteness practices in communicating with others.

In the context of pragmatic developments and this may be the third reason, impoliteness is recently emerged after the study of politeness. If the phenomenon of politeness has been born since the Erving Goffman era in the 1970s, impoliteness has just begun to be widely studied in the 2000s. It was natural for the birth of this new pragmatic phenomenon that has just emerged to be manifesting a very early development. A number of studies on language impoliteness conducted so far, especially in Indonesian language, are still very early studies of language impoliteness.

Furthermore, the concept of implicature was first presented by Grice (1975) in his article entitled 'Logic and Conversation'. One of the impacts of Grice's thought on implicature is the one that eventually leads to a view of language politeness which is based on implied meanings. Rahardi (2012) mentions that the language politeness in the implicature basis was presented by Grice as the 'Gricean View of Politeness'. Thus, it can be emphasized that the view of politeness which is based on the principles of implicature points to the language politeness which was developed by Grice.

In relation to this implicature, Wijana (1996) mentions that a speech can be said to imply a proposition or intention that is not part of the related speech. The implied proposition or intent is referred to as implicature. The relationship between the speech that implies and something that is implied is not an absolute consequence. Therefore, it can be said that in fact the implicature is not really a part of the speech that is implying something. A further illustration of the implicature in pragmatics can be observed on the following speech snippet.

(+) Sendi di mana, Ton?

[Where is Sendi, Ton?]

(-) Andi di rumah neneknya sekarang.

[Andi is at his grandmother's house now.]

At a glance it can be seen that the speech contained in $(+)$ is not related to the speech $(-)$, even it seems that the speech $(-)$ is deviating from the speech $(+)$. However, in fact the speech (-) contains implicature entities. Something that is implied is that 'Andi' is a close friend of 'Sendi'. If 'Andi' is at his grandmother's house, then the implication is that 'Sendi' is also at the house of Andi's grandmother. From the above speech example, it is obvious that something that is implied is not a part of the speech delivered. It even seems as if the speech which is the answer to the previous speech is apart from the form of speech.

In the pragmatic study so far, the implicature in such language practice has been closely observed and studied. There are many studies on the preparation of theses in universities which also take this implicature as the object of their studies. Therefore, it can be said that research and studies on implicature as a pragmatic phenomenon do not need to be re-inflated because that has in fact been done a lot. Nevertheless, if new dimensions are found in the pragmatic implicature, research and studies on this pragmatic phenomenon can also be performed. 
The second pragmatic phenomenon, which has also been widely described, is presupposition. A speech will be said to presuppose another speech if the truth or untruth of a presupposed sentence leads to the truth or untruth that the presupposing sentence could do. The illustration of the statement can be observed through the following speeches.

(-) Anak kecil di rumah besar itu cerdas sekali.

[The child in that big house is very brilliant.]

(+) Istri dosen muda itu cantik sekali.

[The young lecturer's wife is very beautiful.]

What is presupposed in the speech (-) is that in the big house there is a very brilliant little boy. If there is no child in the house, or there may be a small child but that child is not very brilliant, then it can be said that what is presupposed in the speech is wrong. The study of language impoliteness is also closely related to the concept of this presupposition in pragmatics. The context used as the primary device for understanding pragmatic meaning or intent, has a primary substance in the form of assumptions. Thus, it can be said that the study of language politeness is adjacent to the study of presupposition as one of the pragmatic phenomena.

Earlier, it is said that in the implicature, the relationship between something that is implied and a speech that implies something is unnecessary. It can even be said that in the implicature, something that is implied is not a part of the speech that implies something. However, there are times when the relationship between a speech with the other speech is absolutely necessary. In other words, one speech is an entailment of the previous speech. An example can be observed through the following speech.

(-) Kemarin terjadi gempa bumi lagi di Aceh.

[There was an earthquake again in Aceh yesterday.]

$(+)$ Beritanya, tidak lebih dari 10 rumah roboh.

[According to the news, not more than 10 houses collapsed.]

From the previous speech snippets, it can be explained that speech $(+)$ is really a logical and absolute consequence of the speech (-). Therefore, the relationship between the speeches can be said to be obligatory or absolute. That is, the presence of speech $(+)$ is really a logical consequence of the presence of speech (-). Thus, it can be emphasized that speech $(+)$ is an entailment for speech $(-)$, and not a speech that is implied by speech (-). The study of language impoliteness also cannot be separated from the entailment phenomenon as one of the pragmatic phenomena. In the various data of natural speeches that are analyzed to obtain a picture of the pragmatic meaning, there are many facts which have found that they contain this pragmatic phenomenon. Therefore, it can be asserted that the study of language impoliteness cannot detach this other linguistic phenomenon in pragmatics which is commonly referred to as entailment.

Kridalaksana (1993) defines deixis as a thing or function of those points to something outside the language. Meanwhile, Alwi et al. (2003) explains that deixis is a semantic symptom contained in a word or a construction whose reference can only be interpreted by taking into account the situation of the 
conversation. For example the word 'now' can be interpreted as 'right now' or 'this moment'. People might even define that 'now' is this 'second'. However, in other speech, 'now' can be interpreted as merely something that points out time which is different from 'tomorrow' or 'the day after tomorrow'. Thus, it can be said that in the second word 'now', the time period is different from the first 'now'. The difference in the pragmatic meaning or the intent that the word 'now' carries in that context of different speech is what is interpreted as a deictic phenomenon. It should be noted that deixis is not only related to time. Deixis is in fact connected to place as well. In Javanese, when people say 'wanten mrika', then the meaning can vary. The intent contained in the form of 'mrika' might turn out to be 'close' or even might be 'very not close'. Similar with the form of 'di sini' [here] or 'di sana' [there] in Indonesian language that turns out to point at different distances. Although the form of 'here' or 'there' are equally used, different contexts will inevitably produce different meanings as well.

In addition to the deixis of time and place as described previously, there is also deixis of pronoun. The use of the word 'you' can refer to a second person pronoun which only refers to one person. Nevertheless, in a different context, the word 'you' can refer to a second person pronoun which is plural. The word 'you' which refers to a single entity and the word 'you' which refers to a non-singular entity is one example of the use of deixis of pronoun in Indonesian language. For certain people, the form ' $k a m i$ ' [us- exclusive] and the word ' $k i t a$ ' [us- inclusive] mean differently. Meanwhile, some other people refer to ' $k a m i$ ' [us-exclusive] as ' $k i t a$ ' [us-inclusive] and vice versa. For certain, the only entity that will be able to give meaning and determine the meaning precisely is context. Therefore, it can be concluded as well that the phenomenon of deixis in the language is also cannot be separated from the entity of context in understanding it. It is clearly undeniable that the study of language impoliteness can never be detached from the phenomenon of deixis. In fact, sometimes, the form of language impoliteness is linguistically evident in the use of the deictic phenomenon. Hence, it can be said that both of them are in fact closely correlated. The phenomenon of deixis cannot be separated from the phenomenon of language impoliteness, and vice versa.

The concept of chit-chat in language is adjacent to the concept of 'phatic communion' or which is translated into 'fatist communication' conveyed by Malinowski (1923). The word 'phatic' comes from a Greek verb that means 'to speak'. The term 'communion' means the creation of 'ties of union', while 'phatic' is defined as 'by speech' or what is spoken (cf. Mey, 1998, pp.672-673). The phenomenon of chit-chat, as well as the phenomenon of language politeness, is universal. That means, such linguistic phenomena can be found in every language. In Indonesian language, for example, we would very easily find people saying the 'How are you' form of chit-chat, that is when a person is meeting his friend, then the person would easily use that linguistic form. When a colleague has just recovered from his illness and then entering the office, his colleagues would then quickly ask 'Sudah sehat?' [Okay already?] or maybe 'Sehat?' [Okay?] or 'Sehatsehat?' [You okay?].

But in truth, the intent of the speech is not to first ask about the health condition, but only as a sort of chit-chat to ask about the health condition of his colleague. It seems odd that when someone obviously appears to go to a church or to a mosque for worship, someone asks 'Where are you going?'. People, who do 
not understand or do not comprehend the context, may find it very easy to get angry with the linguistic form that is spoken. However, for a person who understands the context, such a speech is simply used to express chit-chat. The main goal of people to chit-chat with each other is to maintain a relationship in the communication practice. Whether people want to use the dimensions of chit-chat or not to use chit-chat in the greetings; it really depends on whether or not they want to be polite or on the contrary they want to express their impoliteness. In other words, the phenomenon of chit-chat is not detached from the phenomenon of language impoliteness. Both can be said to be interrelated, one is present in the other one.

One of the pragmatic phenonema that is now widely studied is the phenomenon of language politeness. Speaking of the concept of language politeness, it is normally divided into two, namely the politeness that is based on the concept of face, and the politeness that is based on the concept of implicature. The first concept was defined by Erving Goffman which was later developed into 'Goffmanian View of Politeness'. The second concept was defined by Grice with his concept of implicature, which then gave birth to 'Gricean View of Politess' (cf. Rahardi, 2013). Speaking of the phenomenon of language politeness, we cannot ignore the politeness principles that Geoffrey N. Leech has conveyed, dividing it into the maxims of politeness. The maxims of politeness of Geoffrey N. Leech can be mentioned one by one as follows. (1) tact maxim: minimize cost to other; maximize benefit to other, (2) generosity maxim: minimize benefit to self; maximize cost to self; (3) approbation maxim: minimize dispraise; maximize praise of other; (4) modesty maxim: minimize praise of self; maximize dispraise of self; (5) agreement maxim: minimize disagreement between self and other; maximize agreement between self and other; (6) sympathy maxim: minimize antipathy between self and other; maximize sympathy between self and other. (cf. Leech, 1983, p.119).

The principle of politeness can be said to be complementary to the principle of cooperation. If the principle of cooperation is widely used for textual pragmatic entities, the principle of politeness is more used with respect to pragmatic entities that are non-textual. Thus, it can be said that the principle of language politeness is actually a complementary of the principle of cooperation. The principle of cooperation can be fully expressed in the following maxims: maxim of quantity, maxim of quality, maxim of relevance, maxim of implementation. (cf. Rahardi, 2009, p.23). From the literature that the researcher can afford, it was found that the study of language politeness developed very quickly after Fraser (1990) showed four models of politeness studies in language, namely (1) a politeness view that is related to social norm, (2) a view that sees politeness as a conversational maxim, (3) a politeness view that is related to the efforts to save the face, and (4) a politeness view that is related to a conversation contract. (cf. Rahardi, 2005, p.38). The relation between the two phenomena in this pragmatic study is very clear and undeniable. Even in the concept of politeness of a number of experts, the phenomenon of impoliteness is considered as a bipolar phenomenon with the phenomenon of language politeness. If there is a term of politeness on one side, it is certain that there will be a term of impoliteness on the other side. Thus, it can be clearly stated that one cannot be separated from the other one that one is intertwining with the other one. 


\section{Conclusion}

As a conclusion, it can be reiterated that in fact the pragmatic phenomena cannot be separated from one another. One linguistic phenomenon is related to other linguistic phenomena. In fact, sometimes, one pragmatic phenomenon is an integral part of other pragmatic phenomena. In connection with that fact, to produce a comprehensive study, a study involving pragmatic phenomena as a whole and integratively is essential to be conducted immediately. With such a holistic and integrative study, the description of pragmatic phenomena in Indonesian language will become more complete and not just fragmented.

\section{References}

Anonymous. (1993). Prinsip-prinsip pragmati. (M.D.D. Oka \& Setyadi Setyapranata, Trans.). Jakarta: Penerbit Universitas Indonesia.

Allan, K. (1986). Linguistic meaning. New York: Routledge \& Kegan Paul Inc.

Blum-Kulka, S. (1987). Indirectness and politeness in requests: Same or different? Journal of Pragmatics 11, 131-146.

Bousfiled, D. \& Miriam A. L. (Eds.). (2008). Impoliteness in language: Studies on its interplay with power in theory and practice. New York: Mouton de Gruyter.

Culpeper, J. (2008). Reflections in impoliteness, relational work and power. In Impoliteness in language: Studies on its interplay with power in theory and practice. New York. Mouton de Gruyter.

Grice, H. P. (1975). Logic and conversation. New York: Academic Press.

Grundy, P. (2000). Doing pracmatics. London: Arnolod.

Leech, G. N. (1983). Principles of pragmatics. London: Longman.

Levinson, S. C. (1983). Pragmatics. London: Cambridge University Press.

Locher, M. A. \& Derek, B. (2008). Impoliteness and power in language. In Impoliteness in language: Studies on its interplay with power in theory and practice. New York. Mouton de Gruyter.

Mahsun. (2005). Metode penulisan bahasa: Tahapan strategi, metode, dan tekniknya. Jakarta: Rajawali Pers.

Mey, J. L. (1994). Pragmatics: An Introduction. Massachusetts: Basil Blackwell Inc.

Morris, C.W. (1938). Foundations of the theory of Signs. In O. Neurah, R. Carnap and C. Morris (Eds.), International encyclopedia of united science. Chicago: University of chacago Press.

Nadar, F. X. (2009). Pragmatik dan penelitian pragmatik. Yogyakarta: Graha Ilmu.

Parker, F. (1986). Linguistics for non linguists. London: Taylor and Francis Ltd.

Rahardi, K. (2004). Berkenalan dengan ilmu bahasa pragmatik. Malang: Dioma.

Rahardi, K. (2006). Pragmatik: Kesantunan imperatif bahasa Indonesia. Jakarta: Erlangga.

Sperber, D. \& Wilson, D. (1986). Relevance: Communication and cognition. Oxford: Basil Blackwell Ltd. 
Stalnaker, R. C. (1973). Pragmatic presupposition. In Munitz, M.K. and D.K. Unger (Eds.), Semantics and Philosophy. New York: New York UniversityPress.

Terkourafi, M. (2008). Toward a unified theory of politeness, impoliteness, and rudeness. In Impoliteness in language: Studies on its interplay with power in theory and practice. New York: Mouton de Gruyter.

Thomas, J. (1983). Cross-cultural pragmatics failure. Applied Linguistics, 4(2), $91-112$.

Verschueren, J. Understanding pragmatics. London: Arnold.

Watts, R. J. \& Miriam, A. L. (2008). Relational work and impoliteness: Negotiating norms of linguistics behavior. In Impoliteness in language: Studies on its interplay with power in theory and practice. New York: Mouton de Gruyter.

Watts, R. J., Sachiko, I. \& Konrad, E. (2005). Politeness in language: Studies in its history, theory and practice. New York: Mouton de Gruyter.

Wierzbicka, A. (1991). Cross-cultural pragmatics: The semantics of human interaction. Berlin: Walter de Gruyter. 